\title{
Nutrient digestibility, ruminal fermentation, and milk yield in dairy cows fed a blend of essential oils and amylase
}

\author{
Guilherme G. Silva, ${ }^{*}$ Caio S. Takiya, ${ }^{*} \dagger$ Tiago A. Del Valle, ${ }^{*}$ Elmeson F. de Jesus, ${ }^{*}$ Nathália T. S. Grigoletto, ${ }^{*}$ \\ Bianca Nakadonari, ${ }^{*}$ Cristina S. Cortinhas, $\ddagger$ Tiago S. Acedo, $\ddagger$ and Francisco P. Rennó*1 \\ *Department of Animal Production and Animal Nutrition, University of São Paulo, Pirassununga 13635-900, Brazil \\ †Department of Animal Sciences and Industry, Kansas State University, Manhattan 66506 \\ fDSM Produtos Nutricionais Brasil S.A., São Paulo 01451-905, Brazil
}

\section{ABSTRACT}

Two experiments were carried out to evaluate a blend of essential oils (EO) combined with amylase as an alternative to ionophores and its potential for reducing the use of antibiotics in the dairy industry. In experiment 1, 8 rumen-cannulated Holstein cows $(576 \pm 100$ $\mathrm{kg}$ of body weight, $146 \pm 35 \mathrm{~d}$ in milk, and $35.1 \pm 4.0$ $\mathrm{kg} / \mathrm{d}$ of milk yield at the start of the experiment) were assigned to a $4 \times 4$ Latin square experiment with 21 -d periods to determine the influence of feed additives on total apparent digestibility of nutrients, ruminal fermentation, N utilization, microbial protein synthesis, blood glucose and urea concentrations, and milk yield and composition in dairy cows. Treatment sequences assigned to cows in each block included no feed additives (control; CON); monensin (MON) added at 13 $\mathrm{mg} / \mathrm{kg}$ of diet dry matter (DM); a blend of EO supplemented at $44 \mathrm{mg} / \mathrm{kg}$ of diet DM; and EO treatment combined with $\alpha$-amylase at 330 kilo novo units $/ \mathrm{kg}$ of diet DM (EOA). Differences among treatments were studied using orthogonal contrasts as follows: CON versus feed additives (MON, EO, and EOA), MON versus EO and EOA, and EO versus EOA. No differences were detected in nutrient intake and digestibility in cows. In general, feed additives decreased ruminal $\mathrm{NH}_{3}-\mathrm{N}$ concentration of cows, notably when diet was supplemented with MON. Furthermore, feed additives increased ruminal concentrations of acetate, butyrate, and branched-chain fatty acids. Cows fed treatments containing EO and EOA exhibited lower $\mathrm{pH}$, higher $\mathrm{NH}_{3}-\mathrm{N}$, and a trend to greater total volatile fatty acid concentration in the ruminal fluid compared with cows fed MON. Treatments containing EO increased ruminal butyrate concentration compared with MON. No treatment $\times$ time interaction effect was observed on

\footnotetext{
Received March 21, 2018.

Accepted June 13, 2018.

${ }^{1}$ Corresponding author: francisco.renno@usp.br
}

ruminal fermentation measurements. Cows fed diets supplemented with feed additives had greater efficiency of $\mathrm{N}$ transfer into milk (milk $\mathrm{N}: \mathrm{N}$ intake), whereas cows fed EOA exhibited greater $\mathrm{N}$ transfer into milk than those fed EO. Treatments had no effect on milk yield and composition, but feed additives increased the milk yield efficiency (milk yield divided by dry matter intake), whereas treatments containing EO had similar milk yield efficiency compared with MON. For experiment 2, 30 multiparous Holstein cows $(574 \pm 68 \mathrm{~kg}$ of body weight, $152 \pm 54 \mathrm{~d}$ in milk, and $30.9 \pm 4.1 \mathrm{~kg} / \mathrm{d}$ of milk yield at the start of the experiment) were enrolled to a randomized complete block design experiment. The MON, EO, and EOA treatments were randomly assigned to cows within blocks $(\mathrm{n}=10)$, and feed additives were provided throughout a 9 -wk period. No differences were found in nutrient intake and digestibility, but cows fed EOA tended to exhibit greater dry matter intake than those fed EO. Blood metabolites and milk production were not affected by treatments. However, cows fed MON or EOA had greater milk protein content than those cows fed treatments containing EO. Feeding EO with or without amylase had similar response to feeding MON in terms of feed intake and milk yield, with a small negative effect on milk protein yield when feeding EO alone. Feed additives increased the concentrations of acetate, butyrate, and branched-fatty acids in ruminal fluid, whereas treatments containing EO had greater ruminal butyrate and $\mathrm{NH}_{3}-\mathrm{N}$ concentrations. Therefore, either EO or EOA can replace MON in diets of dairy cows while maintaining performance.

Key words: $\alpha$-amylase, antimicrobial, ionophore, plant secondary metabolite

\section{INTRODUCTION}

The increasing wealth of emerging economies has promoted the global demand for an adequate and trustworthy supply of meat and milk, which is expected to double by 2050 (Alexandratos and Bruinsma, 2012). 
Despite the necessity of increments in food production, farmers face multiple socioeconomic and environmental challenges, such as pressure to decrease greenhouse gas production, competition for human-edible feedstuff, and a tendency toward a decrease in use of antibiotics and growth promoters in livestock. In this regard, several reviews have highlighted the potential of feed enzymes and plant extracts to improve nutrient utilization in ruminants as alternatives to ionophore antibiotics (Meale et al., 2014; McGrath et al., 2018).

Monensin (MON) is the major ionophore antibiotic used in diets of dairy cows either to improve feed efficiency or to decrease the risk of metabolic disorders such as acidosis and ketosis (Duffield et al., 2008; Gandra et al., 2010). However, use of MON as a feed additive was discontinued by the European Union (Regulation 1831; European Commission, 2003) based on the "precautionary principle." Thus, alternative feed additives to MON have been tested to enhance animal performance. Among the currently marketed feed additives, essential oils (EO) and enzyme products have attracted the attention of the scientific community as potential alternatives to ionophores, especially for being considered "generally recognized as safe" and may improve animal performance (Benchaar et al., 2008; Andreazzi et al., 2018). Essential oils are aromatic compounds extracted from plants by fermentation or distillation (Chao et al., 2000) that exhibit antimicrobial properties, promote propionate production in in vitro studies (Chaves et al., 2008), and may improve milk and FCM production of dairy cows (Kung et al., 2008; Tassoul and Shaver, 2009).

Although enzymes for ruminants have been studied since the 1960s (as reviewed by Beauchemin and Rode, 1996), researchers have re-evaluated their potential in ruminant nutrition in recent years due to increases in feed costs, decreases in enzyme production costs, and greater availability of more active and defined enzyme preparations (Beauchemin et al., 2003). Indeed, the addition of enzyme products with amylase activity in dairy cow diets has increased diet digestibility and milk production of cows (Tricarico et al., 2005; Gencoglu et al., 2010; Andreazzi et al., 2018). Freire et al. (2017) reported greater FCM production in cross-breed dairy cows fed EO combined with amylase (EOA) compared with cows fed MON (22.7 and $22.0 \mathrm{~kg} / \mathrm{d}$, respectively).

Although evidence suggests that EOA can improve milk production of dairy cows, the literature still lacks data regarding the effects of EO and enzyme product combination on ruminal fermentation, digestibility, and performance of dairy cows. Thus, the objective of this study was to evaluate the effects of feed additives $(\mathrm{MON}, \mathrm{EO}$, and $\mathrm{EOA})$ on nutrient intake and total apparent digestibility, ruminal fermentation, microbial protein synthesis, serum glucose and urea concentrations, milk yield and composition, and $\mathrm{N}$ utilization in dairy cows. The hypothesis of this study was that EO and EOA could replace MON in diets of cows without decreasing animal performance. In addition, we expected that the dietary supplementation of EO and amylase would exert synergistic positive effects on ruminal fermentation, nutrient digestibility, and milk production of cows.

\section{MATERIALS AND METHODS}

All experimental procedures with animals were performed with the approval of the ethics committee from the School of Veterinary Medicine and Animal Sciences, University of São Paulo, São Paulo, Brazil (approval no. 9762201015). Two experiments with different designs were performed simultaneously to evaluate the effects of feed additives (MON, EO, and EOA) on ruminal fermentation, $\mathrm{N}$ utilization, and microbial protein synthesis (experiment 1) and to determine their effects on performance of cows (experiment 2). This study was carried out at the Dairy Cattle Research Laboratory, University of São Paulo, Pirassununga, Brazil.

\section{Experiment 1}

Animals, Design, and Treatments. Eight rumencannulated multiparous Holstein cows $(576 \pm 100 \mathrm{~kg}$ of BW, $146 \pm 35 \mathrm{DIM}$, and $35.1 \pm 4.0 \mathrm{~kg} / \mathrm{d}$ of milk yield at the start of the experiment) were enrolled in a replicated $4 \times 4$ Latin square experiment design and distributed to each square according to the milk yield, DIM, and BW. Experimental periods consisted of 14 $\mathrm{d}$ of treatment adaptation and $7 \mathrm{~d}$ of sampling. Treatment sequences were randomly assigned to animals within square and included the following: no feed additives (control; CON); sodium MON added at $13 \mathrm{mg} /$ $\mathrm{kg}$ of diet DM (Rumensin, Elanco, São Paulo, Brazil); a blend of EO supplemented at $44 \mathrm{mg} / \mathrm{kg}$ of DM (Crina Ruminants, DSM Produtos Nutricionais Brasil S.A., São Paulo, Brazil); and provision of EO combined with exogenous $\alpha$-amylase produced by Bacillus licheniformis at 330 kilo novo units/kg of diet DM (Ronozyme Rumistar, DSM Produtos Nutricionais Brasil S.A.). The enzyme product was added in an equivalent dose of $0.55 \mathrm{~g} / \mathrm{kg}$ of DM, which has shown positive effects on the performance of dairy cows (Klingerman et al., 2009; Gencoglu et al., 2010). The Crina Ruminants EO is a patented blend of natural and natural-identical EO compounds that included thymol, eugenol, vanillin, and limonene on an organic carrier (McIntosh et al., 2003). 
Table 1. Ingredient and chemical composition ( $\mathrm{g} / \mathrm{kg}$ of DM, unless otherwise stated) of TMR provided to cows in both experiments

\begin{tabular}{|c|c|}
\hline Item & Amount \\
\hline \multicolumn{2}{|l|}{ Ingredient } \\
\hline Corn silage ${ }^{1}$ & 469 \\
\hline Ground corn & 220 \\
\hline Soybean meal & 152 \\
\hline Citrus pulp & 68.2 \\
\hline Whole raw soybean & 59.5 \\
\hline Vitamin and mineral $\operatorname{mix}^{2}$ & 22.4 \\
\hline Limestone & 3.00 \\
\hline Urea & 2.50 \\
\hline Salt & 2.20 \\
\hline \multicolumn{2}{|l|}{ Chemical composition } \\
\hline $\mathrm{DM}, \mathrm{g} / \mathrm{kg}$ of fresh matter & 448 \\
\hline $\mathrm{OM}$ & 922 \\
\hline $\mathrm{NFC}^{3}$ & 459 \\
\hline Starch & 279 \\
\hline NDF & 295 \\
\hline $\mathrm{ADF}$ & 197 \\
\hline Indigestible $\mathrm{ADF}$ & 77.2 \\
\hline Lignin & 17.0 \\
\hline Neutral detergent insoluble protein & 32.2 \\
\hline Acid detergent insoluble protein & 22.7 \\
\hline $\mathrm{CP}$ & 160 \\
\hline Ether extract & 37.9 \\
\hline Total digestible nutrient $1 x^{4}$ & 753 \\
\hline $\mathrm{NE}_{\mathrm{L}} 3 \times,{ }^{5} \mathrm{Mcal} / \mathrm{kg}$ of $\mathrm{DM}$ & 1.73 \\
\hline
\end{tabular}

${ }^{1}$ Average composition (g/kg of DM, unless otherwise stated): DM, 290 $\mathrm{g} / \mathrm{kg}$ of fresh matter; NDF, 484; indigestible ADF, 148; CP, 72.6; and ash, 57.1.

${ }^{2}$ Per kilogram of mix (minimum values): $88 \mathrm{~g}$ of Ca, $42 \mathrm{~g}$ of $\mathrm{P}, 18 \mathrm{~g}$ of $\mathrm{S}, 45 \mathrm{~g}$ of $\mathrm{Mg}, 20 \mathrm{~g}$ of $\mathrm{K}, 123 \mathrm{~g}$ of Na, $14 \mathrm{mg}$ of Co, $500 \mathrm{mg}$ of $\mathrm{Cu}, 20$ $\mathrm{mg}$ of $\mathrm{Cr}, 1,050 \mathrm{mg}$ of Fe, $28 \mathrm{mg}$ of I, 1,400 $\mathrm{mg}$ of Mn, $18 \mathrm{mg}$ of Se, 2,800 $\mathrm{mg}$ of $\mathrm{Zn}, 80 \mathrm{mg}$ of biotin, 200,000 IU of vitamin A, 70,000 IU of vitamin $\mathrm{D}$, and $1,200 \mathrm{IU}$ of vitamin $\mathrm{E}$.

${ }^{3} \mathrm{NFC}=1,000-[(\mathrm{CP}-\mathrm{CP}$ from urea + urea $)+$ ether extract + ash $+\mathrm{NDF}]$; all values expressed as $\mathrm{g} / \mathrm{kg}$ (Hall, 2000).

${ }^{4}$ Estimated at maintenance level of intake, according to NRC (2001).

${ }^{5}$ Estimated at 3 times maintenance level, according to NRC (2001).

Feed additives (MON, EO, and EOA) were supplied according to the manufacturers' recommendations as dry powders added to the concentrate along with the mineral mixture during the concentrate mixing (once a week). The basal diet was formulated according to NRC (2001) recommendations and fed twice a day (0800 and $1330 \mathrm{~h}$ ) as a TMR (Table 1). Corn silage DM content was assessed on a weekly basis for dietary adjustment purposes. Throughout the experiment, cows were housed in a barn containing individual pens (17.5 $\mathrm{m}^{2}$ of area), sand bedding, feed bunks, and free access to water.

Nutrient Intake and Digestibility. Samples of each ingredient in the concentrate were collected during its preparation, and samples of corn silage and refusals from each cow were collected during the 7 -d sampling periods. Composited samples of feed, refusals, and feces were dried in a forced-air oven at $55^{\circ} \mathrm{C}$ for $72 \mathrm{~h}$ and ground in a Wiley mill (Arthur H. Thomas,
Philadelphia, PA) to pass through a 1-mm screen. The contents of DM (method 930.15, AOAC International, 2000), OM (DM - ash), CP $(\mathrm{N} \times 6.25$; method 984.13, AOAC International, 2000), ether extract (EE; method 920.39, AOAC International, 2000), and starch (Knudsen, 1997) were evaluated in all samples. The contents of NDF, ADF, and lignin in samples were determined according to Van Soest et al. (1991), and results were expressed with residual ash. The NDF analysis was performed using $\alpha$-amylase with no sodium sulfite added to the detergent (TE-149 fiber analyzer, Tecnal Equipment for Laboratory Inc., Piracicaba, Brazil). Total digestible nutrients were calculated according to NRC (2001) equations. Net energy for lactation was estimated according to Weiss et al. (1992). Nonfiber carbohydrate was calculated using the equation proposed by Hall (2000; values expressed as percentages):

$$
\begin{gathered}
\mathrm{NFC}=100-[(\mathrm{CP}-\mathrm{CP} \text { from urea }+ \text { urea }) \\
+\mathrm{NDF}+\mathrm{EE}+\mathrm{ash}] .
\end{gathered}
$$

Fecal samples $(0.3 \mathrm{~kg})$ were collected directly from the rectum of each cow on d 15, 16, and 17 of each experimental period, every $9 \mathrm{~h}$ (starting on d 15 at $0600 \mathrm{~h}$ ), to estimate the amount of daily nutrient excretion. After collection, samples were frozen and composited (wet basis) at the end of each period to form a single sample for each animal per period. Afterward, samples were dried in a forced-air oven at $55^{\circ} \mathrm{C}$ for $72 \mathrm{~h}$ and ground in a Wiley mill (Arthur H. Thomas) to pass through a 2-mm screen. Ground samples (2-mm screen) of feed ingredients, orts, and feces were placed in nonwoven textile bags $(5 \times 5 \mathrm{~cm})$ following the recommendation of a maximum of $20 \mathrm{mg}$ of $\mathrm{DM} / \mathrm{cm}^{2}$ (Nocek, 1988). These samples were incubated for $288 \mathrm{~h}$ in the rumen of 2 Holstein cows previously adapted to the basal diet of this study as described by Casali et al. (2008). After removal from the rumen, bags were washed in running tap water, dried at $55^{\circ} \mathrm{C}$ in a forced-air oven for 72 $\mathrm{h}$, and analyzed for ADF content as described earlier. Fecal samples were evaluated for contents of DM, OM, NDF, starch, CP, and EE as mentioned before. The indigestible ADF (iADF) was used as an internal marker to analyze total-tract digestion, calculated using the following equations:

$$
\text { digestibility of } \mathrm{DM}=1-\left(\frac{\% \text { of iADF intake }}{\% \text { of iADF in feces }}\right) \text {, }
$$

digestibility of nutrient $=$

$$
1-\left[\left(\frac{\% \text { of iADF intake }}{\% \text { of iADF in feces }}\right) \times\left(\frac{\% \text { of nutrient in feces }}{\% \text { of nutrient intake }}\right)\right] \text {. }
$$


Ruminal Fermentation. Ruminal digesta was collected on d 21 of each experimental period, always by the same technician, by withdrawing equal amounts of digesta ( $\sim 500 \mathrm{~g})$ from multiple sites (anterior dorsal, anterior ventral, medium ventral, posterior dorsal, and posterior ventral) within the rumen of cannulated cows. Collections of rumen digesta were performed before the morning feeding (time 0 ) and 2, 4, 6, 8, 10, 12, 14, and $16 \mathrm{~h}$ after the morning feeding. Immediately after each collection, samples were strained through 4 layers of cheesecloth to obtain ruminal fluid $(250 \mathrm{~mL})$. The ruminal fluid $\mathrm{pH}$ was measured using a $\mathrm{pH}$ meter (MB-10, Marte, Santa Rita Sapucai, Brazil). Aliquots of 1,600 $\mu \mathrm{L}$ of sample were mixed with $400 \mu \mathrm{L}$ of methanoic acid $\left(98-100 \% \mathrm{H}_{2} \mathrm{CO}_{2}\right)$ and centrifuged at $7,000 \times g$ for 15 min at $4^{\circ} \mathrm{C}$, and the supernatant of each sample was frozen for posterior VFA analysis. Also, 2-mL aliquots were mixed with $1 \mathrm{~mL}$ of sulfuric acid $(0.5 \mathrm{~mol} / \mathrm{L}$ of $\left.\mathrm{H}_{2} \mathrm{SO}_{4}\right)$ and frozen for analysis of ammonia $\mathrm{N}\left(\mathrm{NH}_{3}-\mathrm{N}\right)$ by the colorimetric phenol-hypochlorite method (Broderick and Kang, 1980).

Ruminal VFA were measured using a gas chromatograph (GC-2014, Shimadzu, Tokyo, Japan) equipped with a capillary column (Stabilwax, Restek, Bellefonte, PA). The gases used were helium as the carrier gas (8.01 $\mathrm{mL} / \mathrm{min}$ flow), hydrogen as the fuel gas (pressure of $60 \mathrm{kPa}$ ), and synthetic air as the oxidizer gas (pressure of $40 \mathrm{kPa}$ ). The steamer temperature was set at $220^{\circ} \mathrm{C}$, the ionization detector flames were set at $250^{\circ} \mathrm{C}$, and the separation column was set at $145^{\circ} \mathrm{C}$ for $3 \mathrm{~min}$, which was then increased $10^{\circ} \mathrm{C} / \mathrm{min}$ up to $200^{\circ} \mathrm{C}$.

$N$ Utilization and Microbial Protein Synthesis. Nitrogen excreted in milk was calculated using the following equation:

$$
\begin{gathered}
\text { milk } N(\mathrm{~g} / \mathrm{d})=\text { milk CP concentration }(\mathrm{g} / \mathrm{kg}) \\
\times \text { milk yield }(\mathrm{kg} / \mathrm{d}) / 6.38
\end{gathered}
$$

Nitrogen excreted in feces was calculated using the following equation:

$$
\begin{aligned}
& \text { fecal } \mathrm{N}(\mathrm{g} / \mathrm{d})=\mathrm{CP} \text { in feces }(\mathrm{g} / \mathrm{kg}) \\
& \times \text { DM fecal excretion }(\mathrm{kg} / \mathrm{d}) / 6.25 \text {. }
\end{aligned}
$$

Samples of urine were collected at the same time points of feces. Urine samples were filtered, and aliquots of 10 $\mathrm{mL}$ were diluted into $40 \mathrm{~mL}$ of $0.036 \mathrm{~N}$ sulfuric acid to avoid bacterial destruction of purine derivatives (PD) and uric acid precipitation and then frozen. Nondiluted urine samples were also frozen for further assessment of $\mathrm{N}$ and creatinine concentrations. Total urine volume was estimated based on the creatinine concentration in urine assuming a daily creatinine excretion of $24.05 \mathrm{mg} /$ $\mathrm{kg}$ of BW (Chizzoti et al., 2008). Urine $\mathrm{N}$ was determined according to AOAC International (2000) method 984.13; hence, urinary $\mathrm{N}$ excretion was calculated by multiplying urine $\mathrm{N}$ by urine volume. Creatinine and uric acid concentrations of urine were determined using commercial kits (Bioclin, Belo Horizonte, Brazil) by colorimetric method, and absorbance was measured in a semiautomatic biochemistry analyzer (SBA-200, CELM, Sao Caetano do Sul, Brazil). Body weights were measured at the beginning of the study and at the last day of each experimental period, before the morning feeding and after milking, using an electronic livestock scale for large animals. Body condition score was measured at the same time points as BW using a 5 -point system ( $1=$ emaciated; $5=$ obese $)$ according to Wildman et al. (1982).

Microbial N synthesis was determined based on PD excretion according to Chen and Gomes (1992). Allantoin in urine and in milk were analyzed by a colorimetric method (Chen and Gomes, 1992). Ten milliliters of milk was mixed with $5 \mathrm{~mL}$ of trichloroacetic acid (25\%); this mixture rested for $5 \mathrm{~min}$ and then was filtered through a paper filter $(14-\mu \mathrm{m}$ pore size) to obtain deproteinized milk samples. The total excretion of PD $(\mathrm{mmol} / \mathrm{d})$ was calculated as the sum of allantoin and uric acid excreted in urine and milk (Orellana Boero et al., 2001). The absorbed PD ( $\left.\mathbf{P D}_{\text {abs }} ; \mathrm{mmol} / \mathrm{d}\right)$ was calculated as follows:

$$
\mathrm{PD}_{\mathrm{abs}}=\left(\mathrm{PD}-0.385 \times \mathrm{BW}^{0.75}\right) / 0.84,
$$

where 0.84 represents the recovery of $\mathrm{PD}_{\text {abs }}$ as $\mathrm{PD}$, and $0.385 \times \mathrm{BW}^{0.75}$ represents the endogenous excretion of PD (Chen and Gomes, 1992). The ruminal synthesis of $\mathrm{N}$ compounds $\left(\mathrm{N}_{\text {mic }}\right.$ g of $\left.\mathrm{N} / \mathrm{d}\right)$ was calculated based on the $\mathrm{PD}_{\mathrm{abs}}$ using the equation of Chen and Gomes (1992):

$$
\mathrm{N}_{\text {mic }}=\left(70 \times \mathrm{PD}_{\text {abs }}\right) /(0.83 \times 0.134 \times 1,000),
$$

where 70 is the $\mathrm{N}$ purine derivative content ( $\mathrm{mg}$ of $\mathrm{N} /$ mol), 0.134 is the ratio between PD $\mathrm{N}$ and microbial $\mathrm{N}$ (Valadares et al., 1999), and 0.83 is the intestinal digestibility of microbial purines.

Milk Yield and Composition. Milk yield was electronically recorded (Alpro, DeLaval, Tumba, Sweden) during all milkings. Milk samples were collected from each cow in all milkings throughout d 17, 18, and 19 of each period and were analyzed for fat, protein, and lactose contents by infrared methodology (Lactoscan, Entelbra, São Paulo, Brazil). The $3.5 \%$ FCM was calculated according to Sklan et al. (1992): 


$$
\begin{aligned}
& 3.5 \% \mathrm{FCM}=(0.432+0.165 \times \text { milk fat }) \\
& \times \text { milk yield }(\mathrm{kg} / \mathrm{d}) .
\end{aligned}
$$

Statistical Analysis. Data were submitted to ANOVA and analyzed using the MIXED procedure of SAS (version 9.3; SAS Institute Inc., Cary, NC) after verifying the normality of residuals and homogeneity of variances by PROC UNIVARIATE, according to the following model:

$$
\mathrm{y}_{i j k l}=\mu+\alpha_{i}+\beta_{j}+\gamma_{l}+\mathrm{c} \gamma_{k l}+\mathrm{e}_{i j k},
$$

where $\mathrm{y}_{i j k l}$ represents the observation on animal $k$ given treatment $i$ at period $j$ in squared $l, \mu$ is the intercept, $\alpha_{i}$ represents the fixed effect of the $i$ th treatment $(i=$ 1 to 4$), \beta_{j}$ represents the fixed effect of the $j$ th period $(j=1$ to 4$), \gamma_{l}=$ represents the fixed effect of the $l$ th square $(l=1$ and 2$), c \gamma_{k l}$ represents the random effect of animal within square $(k=1$ to 8$)$, and $\mathrm{e}_{i j k}$ is the random error associated with each observation.

Repeated measures over time analysis (Littell et al., 2006) using the MIXED procedure of SAS were performed for the ruminal fermentation data $(0,2,4,6,8$, 10,12 , and $16 \mathrm{~h}$ relative to the morning feed) according to the model

$$
\begin{gathered}
\mathrm{y}_{i j k l}=\mu \\
+\alpha_{i}+\beta_{j}+\gamma_{l}+\mathrm{c} \gamma_{k l}+\mathrm{e}(\mathrm{a})_{i j k l} \\
+\delta_{m}+\alpha \delta_{i m}+\mathrm{e}(\mathrm{b})_{i j k l m},
\end{gathered}
$$

where $\mathrm{y}_{i j k l}$ represents the observation on animal $k$ given treatment $i$ at period $j$ in square $l, \mu$ is the intercept, $\alpha_{i}$ represents the fixed effect of the $i$ th treatment $(i=$ 1 to 4$), \beta_{j}$ represents the fixed effect of the $j$ th period $(j=1$ to 4$), \gamma_{l}$ represents the fixed effect of the $l$ th square $(l=1$ to 2$), c \gamma_{k l}$ represents the random effect of animal within square $(k=1$ to 8$), \mathrm{e}_{i j k l m}$ represents the random error associated with each observation of main plot (a), $\delta_{m}$ represents the fixed effect of the $m$ th time $\left(m=0,2,4,6,8,10,12,14\right.$, and 16), $\alpha \delta_{i m}$ represents the fixed effect of interaction between $i$ treatment and $m$ time, and $\mathrm{e}(\mathrm{b})_{i j k l m}$ represents the random error associated with each observation of subplot (b). The Akaike methodology was used to determine the covariance matrix. The degrees of freedom were calculated according to Kenward and Roger (1997). Differences among treatments were analyzed through the following orthogonal contrasts: $\mathrm{C} 1=$ control versus feed additives $(\mathrm{MON}$ $+\mathrm{EO}+\mathrm{EOA}) ; \mathrm{C} 2=$ comparison between ionophore treatment and treatments containing EO (MON vs. EO $+\mathrm{EOA}$ ); and $\mathrm{C} 3=$ effect of $\alpha$-amylase addition (EO vs. EOA). Significance level was $P \leq 0.05$, and trend was $0.05<P \leq 0.10$.

\section{Experiment 2}

A randomized complete block design experiment was carried out to compare the effects of feed additives $(\mathrm{MON}, \mathrm{EO}, \mathrm{EOA})$ for longer periods of supplementation on productive performance of dairy cows. In this experiment, 30 multiparous Holstein cows $(574 \pm 68$ $\mathrm{kg}$ of BW, $152 \pm 54 \mathrm{DIM}$, and $30.9 \pm 4.1 \mathrm{~kg} / \mathrm{d}$ of milk yield at the start of the experiment) were blocked according to DIM, milk yield, and BW. Cows within block were randomly distributed to $\mathrm{MON}, \mathrm{EO}$, or EOA as described in experiment 1 . The experiment lasted $10 \mathrm{wk}$, where the first week was used for sampling to covariate analyses (no feed additives provided) and the following 9 wk were used to evaluate treatment effects. Housing and feeding conditions were the same as those described in experiment 1.

Sampling. Refusals of each animal were collected daily $1 \mathrm{wk}$ before the beginning of feed additive supply (for covariate adjustment purposes) and every 3 wk to determine nutrient intake of the animals. Fecal samples were collected every 3 wk on Friday, Saturday, and Sunday (at $9 \mathrm{~h}$-intervals, starting at $0600 \mathrm{~h}$ on Friday and finishing at $2100 \mathrm{~h}$ on Sunday). Milk yield was recorded in all milkings, and milk was sampled every week on Sunday, Monday, and Tuesday. Methods of chemical analyses were the same as those described in experiment 1. Blood samples were collected $4 \mathrm{~h}$ after the morning feeding every $3 \mathrm{wk}$ (on Thursday) by venipuncture from the coccygeal vein into sterile evacuated containers without clotting activator. After clotting, samples were centrifuged for $15 \mathrm{~min}$ at 2,000 $\times g$ at $4^{\circ} \mathrm{C}$, and the supernatant serum was transferred to centrifuge tubes, which were frozen. Blood serum was analyzed for glucose and urea concentrations using colorimetric commercial kits (Bioclin), and absorbance was measured using a semiautomatic biochemistry analyzer (SBA-200, CELM).

Statistical Analysis. Data were submitted to ANOVA using the MIXED procedure of SAS as repeated measures (Littell et al., 2006) according to the model

$$
\begin{aligned}
& \mathrm{y}_{i j k l}=\mu+\alpha_{i}+\beta_{j}+\omega_{i j}+B_{1}\left(X_{i l}-\bar{X}\right)+\gamma_{l}+\alpha_{i} \\
& +\gamma_{i l}+\mathrm{e}_{i j k l},
\end{aligned}
$$

where $\mathrm{y}_{i j k l}$ represents the observation on animal $k$ given treatment $i$ at period $l$ in block $j, \mu$ is the intercept, $\alpha_{i}$ represents the fixed effect of the $i$ th treatment $(i=1$ to $3), \beta_{j}$ represents the random effect of the $j$ th block $(j=$ 1 to 10$), \omega_{i j}$ is the random error for treatment evaluation (treatment and block interaction effect), $B_{1}$ is a 
Table 2. Nutrient intake and total apparent digestibility in mid-lactation cows fed a blend of essential oils and amylase (experiment 1: Latin square design)

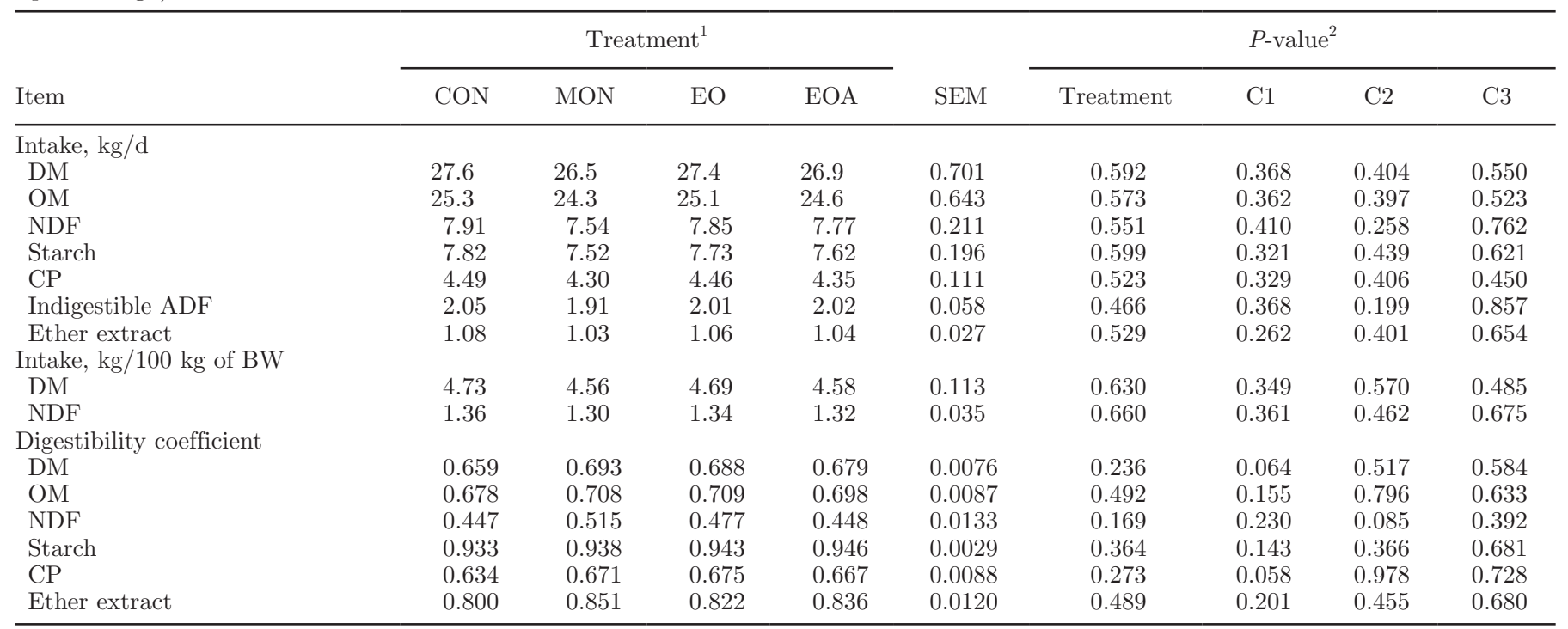

${ }^{1} \mathrm{CON}=$ no feed additive (control); MON = sodium monensin added at $13 \mathrm{mg} / \mathrm{kg}$ (Rumensin, Elanco, São Paulo, Brazil); EO = blend of essential oils supplemented at $44 \mathrm{mg} / \mathrm{kg}$ (Crina Ruminants, DSM Produtos Nutricionais Brasil S.A., São Paulo, Brazil); EOA = provision of essential oils and amylase (330 kilo novo units/kg; Ronozyme Rumistar, DSM Produtos Nutricionais Brasil S.A.).

${ }^{2}$ Orthogonal contrasts: $\mathrm{C} 1=\mathrm{CON}$ vs. feed additives $(\mathrm{MON}+\mathrm{EO}+\mathrm{EOA}) ; \mathrm{C} 2=\mathrm{MON}$ vs. $\mathrm{EO}+\mathrm{EOA}$; $3=\mathrm{EO}$ vs. EOA.

fixed effect regression coefficient, $X_{i l}$ is the covariate measurement of the $k$ th cow within the $j$ th block and ith treatment; $\bar{X}$ is the overall mean of the covariate measurements, $\gamma_{l}$ is the fixed effect of the $l$ th week $(j=$ 1 to 3$), \alpha \times \gamma_{i l}$ is an interaction effect, and $\mathrm{e}_{i j k l}$ is the random residual error. The degrees of freedom were calculated according to Kenward and Roger (1997). The covariance structure for each parameter was determined based on the smallest Akaike information criterion values. Data of DM and nutrient intake, milk yield and composition, BW, and BCS from the first week of the experiment were used as covariates because they reduced Akaike criterion values, and covariate adjustment was not performed for digestibility and serum metabolites concentration data. Differences among treatments were analyzed using orthogonal contrasts: $\mathrm{C} 1$ = comparison between ionophore treatment and treatments containing $\mathrm{EO}(\mathrm{MON}$ vs. $\mathrm{EO}+\mathrm{EOA})$, and $\mathrm{C} 2=$ effect of $\alpha$-amylase addition (EO vs. EOA). Significance level was $P \leq 0.05$, and a trend was $0.05<P$ $\leq 0.10$.

\section{RESULTS}

\section{Experiment 1: Latin Square Design}

In general, feed additives (MON, EO, and EOA) had no effect on feed intake and tended to increase digestibility of DM $(P=0.064)$ and $\mathrm{CP}(P=0.058$; Table
2). Cows fed MON and those fed treatments containing EO (EO and EOA) showed similar $(P \geq 0.199)$ nutrient intake. However, there was a trend for MON to increase $(P=0.085)$ NDF digestibility in cows compared with cows fed EO and EOA. The combination of EO with $\alpha$-amylase (EOA) did not affect $(P \geq 0.392)$ nutrient intake or digestibility in cows in relation to EO.

Feed additives decreased $(P=0.026)$ ruminal $\mathrm{NH}_{3^{-}}$ $\mathrm{N}$ concentration and tended to increase $(P=0.080)$ total VFA concentration in rumen fluid (Table 3 ). Furthermore, treatments containing EO decreased $(P$ $=0.017)$ ruminal $\mathrm{pH}$, increased $\mathrm{NH}_{3}-\mathrm{N}$ concentration $(P=0.004)$, and tended to increase $(P=0.076)$ total VFA ruminal concentration in relation to MON. The EOA treatment tended to decrease $(P=0.065)$ ruminal $\mathrm{NH}_{3}-\mathrm{N}$ concentration without affecting $(P=$ 0.519) VFA concentration in the rumen compared with EO treatment. Regarding the specific ruminal VFA concentration, feed additives increased $(P \leq 0.046)$ the concentrations of acetate, butyrate, and branchedchain fatty acids in the rumen fluid. In addition, cows fed treatments containing EO had greater $(P=0.041)$ ruminal butyrate concentration compared with those cows fed MON. Cows fed EO treatments tended to exhibit greater $(P \leq 0.010)$ concentrations of acetate, propionate, and branched-chain fatty acids in ruminal fluid compared with those fed MON.

Dietary additives improved $(P=0.016) \mathrm{N}$ transfer into the milk and tended to decrease $(P=0.057)$ the 
Table 3. Ruminal fermentation in mid-lactation cows fed a blend of essential oils and amylase (experiment 1: Latin square design)

\begin{tabular}{|c|c|c|c|c|c|c|c|c|c|c|c|}
\hline \multirow[b]{2}{*}{ Item } & \multicolumn{4}{|c|}{ Treatment $^{1}$} & \multirow[b]{2}{*}{ SEM } & \multicolumn{6}{|c|}{$P$-value ${ }^{2}$} \\
\hline & $\mathrm{CON}$ & $\mathrm{MON}$ & EO & EOA & & Treatment & Time & $\begin{array}{l}\text { Treatment } \\
\quad \times \text { time }\end{array}$ & C1 & $\mathrm{C} 2$ & C3 \\
\hline $\mathrm{NH}_{3}-\mathrm{N}, \mathrm{mg} / \mathrm{dL}$ & 18.7 & 15.9 & 18.6 & 17.2 & 0.45 & 0.002 & $<0.001$ & 0.892 & 0.026 & 0.004 & 0.065 \\
\hline Acetate, mol \% & 60.3 & 61.0 & 60.2 & 60.9 & 0.42 & 0.690 & 0.689 & 0.572 & 0.690 & 0.689 & 0.572 \\
\hline Propionate, mol \% & 22.6 & 21.8 & 22.8 & 22.2 & 0.480 & 0.886 & $<0.001$ & 0.591 & 0.794 & 0.539 & 0.670 \\
\hline Total VFA, mM & 146 & 150 & 161 & 167 & 3.27 & 0.095 & $<0.001$ & 0.933 & 0.080 & 0.076 & 0.519 \\
\hline Acetate, $\mathrm{m} M$ & 88.9 & 91.9 & 97.5 & 102 & 1.79 & 0.047 & $<0.001$ & 0.967 & 0.046 & 0.069 & 0.359 \\
\hline Propionate, $\mathrm{m} M$ & 32.7 & 32.7 & 36.8 & 37.1 & 1.15 & 0.240 & $<0.001$ & 0.974 & 0.226 & 0.099 & 0.928 \\
\hline Butyrate, $\mathrm{m} M$ & 17.7 & 18.2 & 19.4 & 20.0 & 0.365 & 0.027 & $<0.001$ & 0.480 & 0.027 & 0.041 & 0.471 \\
\hline BFCA, mM & 6.99 & 7.16 & 7.43 & 7.67 & 0.100 & 0.019 & $<0.001$ & 0.602 & 0.021 & 0.051 & 0.288 \\
\hline $\mathrm{C} 2: \mathrm{C} 3$ ratio & 2.78 & 2.85 & 2.73 & 2.77 & 0.078 & 0.950 & $<0.001$ & 0.754 & 0.971 & 0.589 & 0.835 \\
\hline
\end{tabular}

${ }^{1} \mathrm{CON}=$ no feed additive (control); MON = sodium monensin added at $13 \mathrm{mg} / \mathrm{kg}$ (Rumensin, Elanco, São Paulo, Brazil); EO = blend of essential oils supplemented at $44 \mathrm{mg} / \mathrm{kg}$ (Crina Ruminants, DSM Produtos Nutricionais Brasil S.A., São Paulo, Brazil); EOA = provision of essential oils and amylase (330 kilo novo units/kg; Ronozyme Rumistar, DSM Produtos Nutricionais Brasil S.A.).

${ }^{2}$ Time points $=0,2,4,6,8,10,12,14$, and $16 \mathrm{~h}$ after feeding. Orthogonal contrasts: $\mathrm{C} 1=\mathrm{CON}$ vs. feed additives $(\mathrm{MON}+\mathrm{EO}+\mathrm{EOA}) ; \mathrm{C} 2$ $=\mathrm{MON}$ vs. $\mathrm{EO}+\mathrm{EOA} ; \mathrm{C} 3=\mathrm{EO}$ vs. $\mathrm{EOA}$.

${ }^{3}$ Branched-chain fatty acids.

fecal N (Table 4). Cows fed treatments containing EO tended to show higher $(P=0.073) \mathrm{N}$ balance and lower $(P=0.077) \mathrm{N}$ in urine compared with cows fed MON. Treatments had no effect $(P \geq 0.410)$ on microbial protein synthesis of cows.

Neither tendencies nor treatment effects were observed on milk yield and composition, but feed additives improved $(P=0.040)$ the efficiency of milk production and tended to reduce $(P=0.067)$ the $\mathrm{BW}$ of cows (Table 5). In addition, cows fed EO and EOA had the same efficiency of milk yield as cows fed MON.

\section{Experiment 2: Randomized Complete Block Design}

The EOA treatment tended to increase $(P \leq 0.066)$ DMI and OM intake in comparison with EO (Table 6).
No treatment $\times$ time effect was detected on parameters evaluated. Although milk yield was similar among treatments, milk content of lactose and protein were lesser $(P \leq 0.039)$ in cows fed diets containing EO or EOA than those fed MON (Table 7). Compared with EO alone, EOA increased $(P \leq 0.032)$ milk protein yield and content and milk lactose content. No treatment effects were observed on blood metabolites.

\section{DISCUSSION}

In general, feed additives (MON, EO, and EOA) promoted slight changes in total-tract nutrient digestibility (tended to increase DM digestibility and CP digestibility) without altering DMI of cows. However, the most interesting findings of this study were observed in

Table 4. Nitrogen utilization and microbial protein synthesis in mid-lactation cows fed a blend of essential oils and amylase (experiment 1: Latin square design)

\begin{tabular}{|c|c|c|c|c|c|c|c|c|c|}
\hline Item & \multicolumn{4}{|c|}{ Treatment $^{1}$} & SEM & \multicolumn{4}{|c|}{$P$-value ${ }^{2}$} \\
\hline $\mathrm{N}$ intake, $\mathrm{g} / \mathrm{d}$ & 718 & 688 & 714 & 696 & 17.8 & 0.524 & 0.329 & 0.406 & 0.450 \\
\hline Fecal N, g/g of N intake & 0.366 & 0.329 & 0.326 & 0.333 & 0.0088 & 0.274 & 0.057 & 0.980 & 0.734 \\
\hline Milk $\mathrm{N}, \mathrm{g} / \mathrm{g}$ of $\mathrm{N}$ intake & 0.231 & 0.252 & 0.236 & 0.250 & 0.0071 & 0.013 & 0.016 & 0.141 & 0.046 \\
\hline Urinary $\mathrm{N}, \mathrm{g} / \mathrm{g}$ of $\mathrm{N}$ intake & 0.150 & 0.155 & 0.134 & 0.137 & 0.0050 & 0.263 & 0.463 & 0.077 & 0.861 \\
\hline
\end{tabular}

${ }^{1} \mathrm{CON}=$ no feed additive (control); MON = sodium monensin added at $13 \mathrm{mg} / \mathrm{kg}$ (Rumensin, Elanco, São Paulo, Brazil); EO = blend of essential oils supplemented at $44 \mathrm{mg} / \mathrm{kg}$ (Crina Ruminants, DSM Produtos Nutricionais Brasil S.A., São Paulo, Brazil); EOA = provision of essential oils and amylase (330 kilo novo units/kg; Ronozyme Rumistar, DSM Produtos Nutricionais Brasil S.A.).

${ }^{2}$ Orthogonal contrasts: $\mathrm{C} 1=\mathrm{CON}$ vs. feed additives $(\mathrm{MON}+\mathrm{EO}+\mathrm{EOA}) ; \mathrm{C} 2=\mathrm{MON}$ vs. $\mathrm{EO}+\mathrm{EOA} ; \mathrm{C} 3=\mathrm{EO}$ vs. $\mathrm{EOA}$. 
Table 5. Milk yield and composition, BW, and BCS of mid-lactation cows fed a blend of essential oils and amylase (experiment 1: Latin square design)

\begin{tabular}{|c|c|c|c|c|c|c|c|c|c|}
\hline \multirow[b]{2}{*}{ Item } & \multicolumn{4}{|c|}{ Treatment $^{1}$} & \multirow[b]{2}{*}{ SEM } & \multicolumn{4}{|c|}{$P$-value ${ }^{2}$} \\
\hline & $\mathrm{CON}$ & $\mathrm{MON}$ & $\mathrm{EO}$ & EOA & & Treatment & $\mathrm{C} 1$ & $\mathrm{C} 2$ & C3 \\
\hline \multicolumn{10}{|l|}{ Yield, kg/d } \\
\hline Milk & 34.6 & 35.9 & 35.0 & 35.3 & 0.74 & 0.300 & 0.156 & 0.220 & 0.703 \\
\hline $\mathrm{FCM}^{3}$ & 32.8 & 33.9 & 32.4 & 34.0 & 0.78 & 0.513 & 0.548 & 0.533 & 0.221 \\
\hline Lactose & 1.56 & 1.63 & 1.57 & 1.61 & 0.034 & 0.389 & 0.294 & 0.288 & 0.376 \\
\hline Fat & 1.10 & 1.08 & 1.07 & 1.16 & 0.039 & 0.665 & 0.894 & 0.647 & 0.258 \\
\hline Lactose & 45.3 & 45.4 & 45.5 & 45.6 & 0.28 & 0.693 & 0.438 & 0.408 & 0.727 \\
\hline Fat & 32.3 & 31.6 & 31.2 & 32.3 & 0.85 & 0.807 & 0.591 & 0.880 & 0.429 \\
\hline Protein & 30.2 & 30.3 & 30.4 & 30.4 & 0.18 & 0.639 & 0.262 & 0.713 & 0.627 \\
\hline Efficiency $^{4}$ & 1.28 & 1.38 & 1.31 & 1.36 & 0.040 & 0.074 & 0.040 & 0.242 & 0.194 \\
\hline $\mathrm{BW}, \mathrm{kg}$ & 602 & 600 & 596 & 598 & 16.8 & 0.520 & 0.067 & 0.921 & 0.157 \\
\hline BCS & 2.53 & 2.53 & 2.50 & 2.50 & 0.009 & 0.371 & 0.317 & 0.161 & 0.231 \\
\hline
\end{tabular}

${ }^{1} \mathrm{CON}=$ no feed additive (control); $\mathrm{MON}=$ sodium monensin added at $13 \mathrm{mg} / \mathrm{kg}$ (Rumensin, Elanco, São Paulo, Brazil); EO = blend of essential oils supplemented at $44 \mathrm{mg} / \mathrm{kg}$ (Crina Ruminants, DSM Produtos Nutricionais Brasil S.A., São Paulo, Brazil); EOA = provision of essential oils and amylase (330 kilo novo units/kg; Ronozyme Rumistar, DSM Produtos Nutricionais Brasil S.A.).

${ }^{2}$ Orthogonal contrasts: $\mathrm{C} 1=\mathrm{CON}$ vs. feed additives $(\mathrm{MON}+\mathrm{EO}+\mathrm{EOA}) ; \mathrm{C} 2=\mathrm{MON}$ vs. $\mathrm{EO}+\mathrm{EOA} ; \mathrm{C} 3=\mathrm{EO}$ vs. $\mathrm{EOA}$.

${ }^{3} 3.5 \% \mathrm{FCM}=(0.432+0.165 \times \%$ fat in milk $) \times$ milk yield $(\mathrm{kg} / \mathrm{d})$ according to Sklan et al. (1992).

${ }^{4}$ Efficiency $=$ milk yield $(\mathrm{kg} / \mathrm{d}) / \mathrm{DMI}(\mathrm{kg} / \mathrm{d})$.

ruminal fermentation wherein feed additives increased acetate, butyrate, and branched-chain fatty acid concentrations. In addition, feed additives containing EO $(\mathrm{EO}+\mathrm{EOA})$ tended to increase or increased total VFA, acetate, propionate, butyrate, and branched-chain fatty acid concentrations in the rumen of cows. Because of these effects, treatments containing EO improved the feed efficiency and $\mathrm{N}$ utilization of cows.
In agreement with the current study, other authors reported no effects on DMI and total apparent digestibility when supplementing MON (Ferreira de Jesus et al., 2016; Vendramini et al., 2016), EO (Benchaar et al., 2006, 2007; Vendramini et al., 2016), or products containing amylase (Nozière et al., 2014; Takiya et al., 2017 ) to lactating dairy cows. On the other hand, exogenous amylase has increased feed efficiency in dairy

Table 6. Nutrient intake and total apparent digestibility in mid-lactation cows fed a blend of essential oils and amylase (experiment 2: randomized complete block design)

\begin{tabular}{|c|c|c|c|c|c|c|c|c|c|}
\hline \multirow[b]{2}{*}{ Item } & \multicolumn{3}{|c|}{ Treatment $^{1}$} & \multirow[b]{2}{*}{ SEM } & \multicolumn{5}{|c|}{$P$-value ${ }^{2}$} \\
\hline & $\mathrm{MON}$ & $\mathrm{EO}$ & EOA & & Treatment & Time & $\begin{array}{l}\text { Treatment } \\
\times \text { time }\end{array}$ & $\mathrm{C} 1$ & $\mathrm{C} 2$ \\
\hline DM & 22.8 & 22.4 & 23.6 & 0.31 & 0.157 & $<0.001$ & 0.139 & 0.716 & 0.062 \\
\hline $\mathrm{OM}$ & 20.9 & 20.6 & 21.7 & 0.28 & 0.164 & $<0.001$ & 0.122 & 0.698 & 0.066 \\
\hline Starch & 9.71 & 9.85 & 10.0 & 0.147 & 0.625 & 0.746 & 0.794 & 0.732 & 0.604 \\
\hline Indigestible ADF & 1.69 & 1.68 & 1.71 & 0.026 & 0.862 & 0.009 & 0.498 & 0.814 & 0.633 \\
\hline Ether extract & 0.90 & 0.91 & 0.93 & 0.014 & 0.637 & 0.605 & 0.667 & 0.444 & 0.605 \\
\hline \multicolumn{10}{|c|}{ Digestibility coefficient } \\
\hline DM & 0.680 & 0.689 & 0.690 & 0.0045 & 0.581 & 0.005 & 0.512 & 0.302 & 0.968 \\
\hline $\mathrm{OM}$ & 0.700 & 0.711 & 0.710 & 0.0049 & 0.579 & 0.060 & 0.361 & 0.301 & 0.971 \\
\hline Starch & 0.843 & 0.858 & 0.856 & 0.0057 & 0.480 & 0.026 & 0.141 & 0.235 & 0.864 \\
\hline $\mathrm{NDF}$ & 0.466 & 0.473 & 0.481 & 0.0084 & 0.703 & 0.030 & 0.760 & 0.475 & 0.666 \\
\hline
\end{tabular}

${ }^{1} \mathrm{CON}=$ no feed additive (control); $\mathrm{MON}=$ sodium monensin added at $13 \mathrm{mg} / \mathrm{kg}$ (Rumensin, Elanco, São Paulo, Brazil); EO = blend of essential oils supplemented at $44 \mathrm{mg} / \mathrm{kg}$ (Crina Ruminants, DSM Produtos Nutricionais Brasil S.A., São Paulo, Brazil); EOA = provision of essential oils and amylase (330 kilo novo units/kg; Ronozyme Rumistar, DSM Produtos Nutricionais Brasil S.A.).

${ }^{2}$ Time: weeks. Orthogonal contrasts: $\mathrm{C} 1=\mathrm{MON}$ vs. EO + EOA; 2 , = EO vs. EOA. 
cows, but differences were attributed to decreased DMI while maintaining milk production (Gencoglu et al., 2010; Ferraretto et al., 2011). Essential oils either tended to improve or improved the feed efficiency with no effects on DMI in early-lactating cows (Tassoul and Shaver, 2009; Drong et al., 2016). Thus, it is reasonable that either EO or EOA would increase feed efficiency of dairy cows. Positive responses to dietary additives, such as enzymes and EO, are more prone to be observed in situations in which fiber digestibility is impaired or when energy is the first limiting nutrient to milk production, as occur during early lactation (Beauchemin et al., 2003).

Feed additives decreased $\mathrm{NH}_{3}-\mathrm{N}$ concentration in the rumen, especially due to the lowest value of ruminal $\mathrm{NH}_{3}-\mathrm{N}$ concentration in cows treated with MON. Earlier studies indicated that MON decreases AA deamination and consequently reduces $\mathrm{NH}_{3}-\mathrm{N}$ accumulation in the rumen (Yang and Russell, 1993). In addition, authors demonstrated that MON inhibits hyperammonia-producing bacteria (Ruiz et al., 2001). The blend of EO supplied to cows in the current experiment also has been associated with decreases in ruminal deamination. McIntosh et al. (2003) reported that pure cultures of hyperammonia-producing bacteria (i.e., Clostridium sticklandii and Peptostreptococcus anaerobius) are very sensitive to EO. Giannenas et al. (2011) also found a decrease in hyperammonia-producing bacteria counts in dairy ewes fed EO. However, there was a tendency in the EOA group to accumulate less $\mathrm{NH}_{3}-\mathrm{N}$ in the ru- men compared with cows fed EO. The explanation for the latter outcome is not clear because products with $\alpha$-amylase activity have not affected ruminal $\mathrm{NH}_{3}-\mathrm{N}$ concentration (DeFrain et al., 2005; Tricarico et al., 2005; Nozière et al., 2014; Takiya et al., 2017). Rather than a decrease in deamination, EOA treatment could increase $\mathrm{NH}_{3}-\mathrm{N}$ utilization by fibrolytic bacteria or increase the substrate available for microbial protein synthesis, hence turning it more efficient. Tricarico et al. (2008) added $\alpha$-amylase to a culture medium rich in starch and observed rapid growth of Butyrivibrio fibrisolvens D1, which have high fibrolytic activity.

Indeed, dietary additives affected ruminal fermentation by increasing all VFA concentration in the rumen (with the exception of propionate), suggesting an increase in ruminal digestibility of nutrients. To the best of our knowledge, no in vivo study has evaluated the effects of EO on ruminal digestibility of nutrients in dairy cows. Cows fed treatments containing EO had the lowest ruminal $\mathrm{pH}$ values, which is associated with the highest values of ruminal total VFA concentrations. The effects of EO on total VFA concentration in ruminal fluid have been inconsistent in in vitro and in vivo studies (Castillejos et al., 2005; Benchaar et al., 2007; Vendramini et al., 2016). Castillejos et al. (2005) observed an increase in the total VFA production using a continuous culture with a substrate containing forage:concentrate ratio of 60:40 (alfalfa silage as forage source) and EO. Benchaar et al. (2007) found higher values of total VFA production when providing EO

Table 7. Milk yield and composition and blood metabolites in mid-lactation cows fed a blend of essential oils and amylase (experiment 2: randomized complete block design)

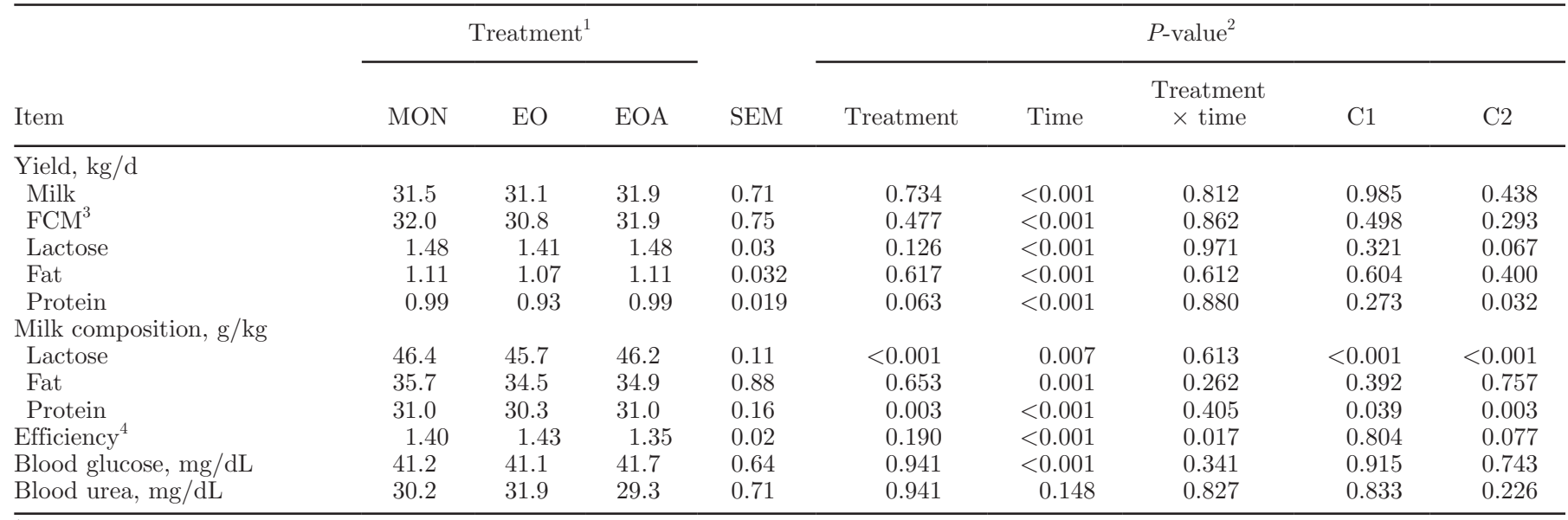

${ }^{1} \mathrm{CON}=$ no feed additive (control); MON = sodium monensin added at $13 \mathrm{mg} / \mathrm{kg}$ (Rumensin, Elanco, São Paulo, Brazil); EO = blend of essential oils supplemented at $44 \mathrm{mg} / \mathrm{kg}$ (Crina Ruminants, DSM Produtos Nutricionais Brasil S.A., São Paulo, Brazil); EOA = provision of essential oils and amylase (330 kilo novo units/kg; Ronozyme Rumistar, DSM Produtos Nutricionais Brasil S.A.).

${ }^{2}$ Time: weeks. Orthogonal contrasts: $\mathrm{C} 1=\mathrm{MON}$ vs. $\mathrm{EO}+\mathrm{EOA} ; \mathrm{C} 2,=\mathrm{EO}$ vs. EOA.

${ }^{3} 3.5 \% \mathrm{FCM}=(0.432+0.165 \times \%$ fat in milk $) \times$ milk yield $(\mathrm{kg} / \mathrm{d})$, according to Sklan et al. (1992).

${ }^{4}$ Efficiency $=$ milk yield $(\mathrm{kg} / \mathrm{d}) / \mathrm{DMI}(\mathrm{kg} / \mathrm{d})$. 
to cows fed alfalfa silage as a forage source, but they reported a slight decrease in VFA production when providing $\mathrm{EO}$ to cows fed corn silage as a dietary forage source. One possible reason for trends toward a greater ruminal concentration of total VFA and butyrate in cows fed EO (besides the increase of ruminal digestibility of nutrients) is that branched-chain fatty acids can stimulate cellulolytic bacteria activity (Buttery and Foulds, 1985), which could favor acetate and butyrate fermentation pathways. Combining amylase with EO seems to not have any beneficial effect on ruminal fermentation because similar values of VFA concentration and VFA molar proportions were found in cows fed EO or EOA. Few studies assessed the ruminal fermentation of cows fed amylase derived from B. licheniformis, but amylase has increased the propionate molar proportion in first-lactation cows fed high-starch diets (Nozière et al., 2014), contrasting with what was observed in the current study.

Feed additives tended to decrease the fecal $\mathrm{N}$ excretion and improved $\mathrm{N}$ transfer into milk. These outcomes can be explained by the lower $\mathrm{NH}_{3}-\mathrm{N}$ accumulation in the rumen and the trend toward a greater $\mathrm{CP}$ digestibility in cows fed feed additives. Low efficiencies of dietary $\mathrm{N}$ utilization for milk protein synthesis are partially related to $\mathrm{NH}_{3}-\mathrm{N}$ losses in the rumen (Tamminga, 1992). In the current experiment, feed additives increased the concentration of several VFA, which indicates a greater energy availability for $\mathrm{NH}_{3}-\mathrm{N}$ uptake by the rumen bacteria. Because rumen microbes largely depend on $\mathrm{NH}_{3}-\mathrm{N}$ to synthesize protein (Hristov and Broderick, 1996), enhancing microbial protein synthesis would promote $\mathrm{N}$ transfer into milk.

In experiment 1 , treatments had no effect on milk yield and composition of dairy cows, but feed additives increased the efficiency of milk production. Feed additives tended to increase DM digestibility while presenting similar DMI in relation to $\mathrm{CON}$, which partially explains the increased efficiency of milk yield in cows. In addition, the greater concentrations of acetate and butyrate in the rumen suggest an increase of DM degradation in the rumen. Interestingly, EO and EOA showed similar outcomes for milk production efficiency compared with MON in both experiments. The positive effects of MON on milk production efficiency in dairy cows is supported by Duffield et al. (2008), who performed a meta-analysis from 77 trials and reported an increase of $2.5 \%$ on milk production efficiency (energy basis) of cows fed MON. The milk production outcomes when feeding EO are inconsistent. For instance, Freire et al. (2017) reported an increase in FCM and ECM production of cross-breed cows supplemented with EOA. Contrasting with the current experiment,
Khiaosa-ard and Zebeli (2013) reported no effect of EO supplementation to dairy cows on milk production efficiency after analyzing data from 15 experiments with different blends of EO or a single extract. In experiment 2, treatments containing EO decreased milk lactose and protein content in relation to MON, whereas EOA improved the milk lactose and protein content in relation to EO. The reasons for differences in milk lactose content are not clear because ruminal propionate and blood glucose concentrations were not affected by treatments. The differences in milk protein content are likely related to ruminal $\mathrm{NH}_{3}-\mathrm{N}$ concentration outcomes.

\section{CONCLUSIONS}

This study demonstrated the potential effects of feed additives (MON, EO, and EOA) on rumen fermentation, whereas the combination of $\mathrm{EO}$ and $\alpha$-amylase increased ruminal concentration of acetate, butyrate, and branched-chain fatty acids while decreasing ruminal concentration of $\mathrm{NH}_{3}-\mathrm{N}$. Further, EOA improved $\mathrm{N}$ transfer into milk compared with EO alone but had small effects on milk production and composition of cows. Milk production efficiency was improved by feed additives, and the second experiment demonstrated no differences in milk production efficiency among them. Either EO or EOA can replace MON without decreasing animal performance. There is no evidence that EO along with amylase has a positive synergistic effect on milk yield, but EOA may increase milk protein content and production.

\section{ACKNOWLEDGMENTS}

The authors acknowledge the University of São Paulo and Dairy Cattle Research Laboratory for providing the infrastructure and staff necessary for this study. The authors are grateful to DSM Produtos Nutricionais Brasil S.A. (São Paulo, Brazil) for supplying feed additives. Finally, the authors express their appreciation to São Paulo Research Foundation (FAPESP; São Paulo, Brazil) for awarding a fellowship to the first author (grant no. 16/02445-8).

\section{REFERENCES}

Alexandratos, N., and J. Bruinsma. 2012. World Agriculture Towards 2030/2050. Food and Agriculture Organization of the United Nations, Rome, Italy.

Andreazzi, A. S. R., M. N. Pereira, R. B. Reis, R. A. N. Pereira, N. N. Morais Júnior, T. S. Acedo, R. G. Hermes, and C. S. Cortinhas. 2018. Effect of exogenous amylase on lactation performance of dairy cows fed a high-starch diet. J. Dairy Sci. 101:7199-7207. 
AOAC International. 2000. Official Methods of Analysis. 17th ed. AOAC Int., Arlington, VA.

Beauchemin, K. A., D. Colombatto, D. P. Morgavi, and W. Z. Yang. 2003. Use of exogenous fibrolytic enzymes to improve feed utilization by ruminants. J. Anim. Sci. 81(E-Suppl.):E37-E47.

Beauchemin, K. A., and L. M. Rode. 1996. The potential use of feed enzymes for ruminants. Pages 131-141 in Proc. Cornell Nutrition Conference for Feed Manufacturers. Cornell University, Ithaca, NY.

Benchaar, C., S. Calsamiglia, A. V. Chaves, G. R. Fraser, D. Colombatto, T. A. McAllister, and K. A. Beauchemin. 2008. A review of plant-derived essential oils in ruminant nutrition and production. Anim. Feed Sci. Technol. 145:209-228.

Benchaar, C., H. V. Petit, R. Berthiaume, D. R. Quellet, J. Chiquette, and P. Y. Chouinard. 2007. Effects of essential oils on digestion, ruminal fermentation, rumen microbial populations, milk production, and milk composition in dairy cows fed alfalfa silage or corn silage. J. Dairy Sci. 90:886-897.

Benchaar, C., H. V. Petit, R. Berthiaume, T. D. Whyte, and P. Y. Chouinard. 2006. Effect of addition of essential oils and monensin premix on digestion, ruminal fermentation, milk production, and milk composition in dairy cows. J. Dairy Sci. 89:4352-4364.

Broderick, G. A., and J. H. Kang. 1980. Automated simultaneous determination of ammonia and total amino acids in ruminal fluid and in vitro media. J. Dairy Sci. 63:64-75.

Buttery, P. J., and A. N. Foulds. 1985. Amino acid requirements of ruminants. Pages 257-271 in Recent Advances in Animal Nutrition. W. Haresign and D. J. A. Cole, ed. Butterworths, London, UK.

Casali, A. O., E. Detman, and S. C. Valadares Filho. 2008. Influência do tempo de incubação e do tamanho de partículas sobre os teores de compostos indigestíveis em alimentos e fezes bovinas obtidos por procedimentos in situ. Rev. Bras. Zootec. 37:335-342.

Castillejos, L., S. Calsamiglia, A. Ferret, and R. Losa. 2005. Effects of a specific blend of essential oil compounds and the type of diet on rumen microbial fermentation and nutrient flow from a continuous culture system. Anim. Feed Sci. Technol. 119:29-41.

Chao, S. C., D. G. Young, and C. J. Oberg. 2000. Screening for inhibitory activity of essential oils on selected bacteria, fungi and viruses. J. Essent. Oil Res. 12:639-649.

Chaves, A. V., M. L. He, W. Z. Yang, A. N. Hristov, T. A. Mcallister, and C. Benchaar. 2008. Effects of essential oils on the proteolytic, deaminative and methanogenic activities of mixed ruminal bacteria. Can. J. Anim. Sci. 88:117-122.

Chen, X. B., and M. J. Gomes. 1992. Estimation of microbial protein supply to sheep and cattle based on urinary excretion of purine derivatives - An overview of technical details. International Feed Research Unit, Rowett Research Institute, Bucksburnd, UK.

Chizzoti, M. L., S. C. Valadares Filho, R. F. D. Valadares, F. H. M. Chizzotti, and L. O. Tedeschi. 2008. Determination of creatinine excretion and evaluation of spot urine sampling in Holstein cattle. Livest. Prod. Sci. 113:218-225.

DeFrain, J. M., A. R. Hippen, K. F. Kalscheur, and J. M. Tricarico. 2005. Effects of dietary $\alpha$-amylase on metabolism and performance of transition dairy cows. J. Dairy Sci. 88:4405-4413.

Drong, C., U. Meyer, D. von Soosten, J. Frahm, J. Rehage, G. Breves, and S. Danicke. 2016. Effect of monensin and essential oils on performance and energy metabolism of transition dairy cows. J. Anim. Physiol. Anim. Nutr. (Berl.) 100:537-551.

Duffield, T. F., A. Rabiee, and I. J. Lean. 2008. A meta-analysis of the impact of monensin in lactating dairy cattle. Part 2. Production effects. J. Dairy Sci. 91:1347-1360.

European Commission. 2003. Regulation (EC) No. 1831/2003 of the European parliament and of the council of 22 September 2003 on additives for use in animal nutrition. Off. J. L268:229-243.

Ferrareto, L. F., R. D. Shaver, M. Espineira, H. Gencoglu, and S. J. Bertics. 2011. Influence of a reduced-starch diet with or without exogenous amylase on lactation performance by dairy cows. J. Dairy Sci. 94:1490-1499.

Ferreira de Jesus, E., T. A. Del Valle, G. D. Calomeni, T. H. Silva, C. S. Takiya, T. H. A. Vendramini, P. G. Paiva, G. G. Silva, A. S. Netto, and F. P. Rennó. 2016. Influence of a blend of functional oils or monensin on nutrient intake and digestibility, ruminal fermentation and milk production of dairy cows. Anim. Feed Sci. Technol. 219:59-67.

Freire, L. D. R., T. R. Tomich, A. L. Ferreira, F. S. Machado, C. S. Cortinhas, T. S. Acedo, M. S. Pedreira, and L. G. R. Pereira. 2017. Effects of amylase and essential oils in cross-breed dairy cow diets: Milk composition and production. Page 1027 in Proc. 54th Reunião Anual da Sociedade Brasileira de Zootecnia. Foz do Iguaçu, Brazil.

Gandra, J. R., F. P. Rennó, J. E. Freitas Júnior, M. V. Santos, L. F. Prada e Silva, and A. P. C. Araújo. 2010. Productive performance and milk protein fraction composition of dairy cows supplemented with sodium monensin. Rev. Bras. Zootec. 39:1810-1817.

Gencoglu, H., R. D. Shaver, W. Steinberg, J. Ensink, L. F. Ferrareto, S. J. Bertics, J. C. Lopes, and M. S. Akins. 2010. Effect of feeding a reduced-starch diet with or without amylase addition on lactation performance in dairy cows. J. Dairy Sci. 93:723-732.

Giannenas, I., J. Skoufos, C. Giannakopoulos, M. Wieman, O. Gortzi, S. Lalas, and I. Kyriazakis. 2011. Effects of essential oils on milk production, milk composition, and rumen microbiota in Chios dairy ewes. J. Dairy Sci. 94:5569-5577.

Hall, M. B. 2000. Calculation of non-structural carbohydrate content of feeds that contain non-protein nitrogen. Bulletin 339. University of Florida, Gainesville.

Hristov, A. N., and G. A. Broderick. 1996. Ruminal microbial protein synthesis in cows fed alfalfa silage, alfalfa hay or corn silage and fitted with only ruminal cannula. J. Dairy Sci. 79:1627-1637.

Kenward, M. G., and J. H. Roger. 1997. Small sample inference for fixed effects from restricted maximum likelihood. Biometrics 53:983-997.

Khiaosa-ard, R., and Q. Zebeli. 2013. Meta-analysis of the effects of essential oils and their bioactive compounds on rumen fermentation characteristics and feed efficiency in ruminants. J. Anim. Sci. 91:1819-1830.

Klingerman, C. M., W. Hu, E. E. McDonell, M. C. Derbedrosian, and L. Kung Jr. 2009. An evaluation of exogenous enzymes with amylolytic activity for dairy cows. J. Dairy Sci. 92:1050-1059.

Knudsen, K. E. B. 1997. Carbohydrate and lignin contents of plant materials used in animal feeding. Anim. Feed Sci. Technol. 67:319338.

Kung, L. Jr., P. Williams, R. J. Schmidt, and W. Hu. 2008. A blend of essential plant oils used as an additive to alter silage fermentation or used as a feed additive for lactating dairy cows. J. Dairy Sci. 91:4793-4800.

Littell, R. C., G. A. Milliken, W. W. Stroup, and R. D. Wolfinger. 2006. SAS System for Mixed Models. 2nd ed. SAS Institute Inc., Cary, NC.

McGrath, J., S. M. Duval, L. F. M. Tamassia, M. Klindermann, R. T. Stemmler, V. N. Gouvea, T. S. Acedo, I. Immig, S. N. Williams, and P. Celi. 2018. Nutritional strategies in ruminants: A lifetime approach. Res. Vet. Sci. 116:28-39.

McIntosh, F. M., P. Williams, R. Losa, R. J. Wallace, D. A. Beever, and C. J. Newbold. 2003. Effects of essential oils on ruminal microorganisms and their protein metabolism. Appl. Environ. Microbiol. 69:5011-5014.

Meale, S. J., K. A. Beauchemin, A. N. Hristov, A. V. Chaves, and T. A. McAllister. 2014. Board-invited review: Opportunities and challenges in using exogenous enzymes to improve ruminant production. J. Anim. Sci. 92:427-442.

National Research Council. 2001. Nutrient Requirements of Dairy Cattle. 7th rev. ed. Nat. Acad. Press, Washington, DC.

Nocek, J. E. 1988. In situ and other methods to estimate ruminal protein and energy digestibility: A review. J. Dairy Sci. 71:2051-2069.

Nozière, P., W. Steinberg, M. Silberberg, and D. P. Morgavi. 2014. Amylase addition increases starch ruminal digestion in first-lactation cows fed high and low starch diets. J. Dairy Sci. 97:2319-2328.

Orellana Boero, P., J. Balcells, S. M. Martín-Orúe, J. B. Liang, and J. A. Guada. 2001. Excretion of purine derivatives in cows: Endogenous contribution and recovery of exogenous purine bases. Livest. Prod. Sci. 68:243-250. 
Ruiz, R., G. L. Albrecht, L. O. Tedeschi, G. Jarvis, J. B. Russel, and D. G. Fox. 2001. Effect of monensin on the performance and nitrogen utilization of lactating dairy cows consuming fresh forage. J. Dairy Sci. 84:1717-1727.

Sklan, D., R. Ashkennazi, A. Braun, A. Devorin, and K. Tabori. 1992. Fatty acids, calcium soaps of fatty acids, and cottonseeds fed to high yielding cows. J. Dairy Sci. 75:2463-2472.

Takiya, C. S., G. D. Calomeni, T. H. Silva, T. H. A. Vendramini, G. G. Silva, C. E. C. Consentini, J. C. Bertoni, E. M. C. Zilio, and F. P. Rennó. 2017. Increasing doses of an Aspergillus oryzae extract with alpha-amylase activity on nutrient digestibility and rumina fermentation of lactating dairy cows. Anim. Feed Sci. Technol. 228:159-167.

Tamminga, S. 1992. Nutrition management of dairy cows as a contribution to pollution control. J. Dairy Sci. 75:345-357.

Tassoul, M. D., and R. D. Shaver. 2009. Effect of a mixture of supplemental dietary plant essential oils on performance of periparturient and early lactation dairy cows. J. Dairy Sci. 92:1734-1740.

Tricarico, J. M., J. D. Johnson, and K. A. Dawson. 2008. Dietary supplementation of ruminant diets with an Aspergillus oryzae $\alpha$-amylase. Anim. Feed Sci. Technol. 145:136-150.

Tricarico, J. M., J. D. Johnston, K. A. Dwason, K. C. Hanson, K. R. McLeod, and D. L. Harmon. 2005. The effects of an Aspergillus oryzae extract containing alpha amylase activity on ruminal fer- mentation and milk production in lactating Holstein cows. Anim. Sci. 81:365-374.

Valadares, R. F. D., G. A. Broderick, S. C. Valadares Filho, and M. K. Clayton. 1999. Effect of replacing alfalfa silage with high moisture corn on ruminal protein synthesis estimated from excretion of total purine derivatives. J. Dairy Sci. 82:2686-2696.

Van Soest, P. J., J. B. Robertson, and B. A. Lewis. 1991. Methods for dietary fiber, neutral detergent fiber, and nonstarch polysaccharides in relation to animal nutrition. J. Dairy Sci. 74:3583-3597.

Vendramini, T. H. A., C. S. Takiya, T. H. Silva, F. Zanferari, M. F. Rentas, J. C. Bertoni, C. E. C. Consentini, R. Gardinal, T. S. Acedo, and F. P. Rennó. 2016. Effects of a blend of essential oils, chitosan or monensin on nutrient intake and digestibility of lactating dairy cows. Anim. Feed Sci. Technol. 214:12-21.

Weiss, W. P., H. R. Conrad, and N. R. St-Pierre. 1992. A theoreticallybased model for predicting total digestible nutrient values of forages and concentrates. Anim. Feed Sci. Technol. 39:95-110.

Wildman, E. E., G. M. Jones, P. E. Wagner, and R. L. Boman. 1982 A dairy body condition scoring system and its relationship to selected production characteristics. J. Dairy Sci. 65:495-501.

Yang, C. M., and J. B. Russell. 1993. Effect of monensin on the specific activity of ammonia production by ruminal bacteria and disappearance of amino nitrogen from the rumen. Appl. Environ. Microbiol. 59:3250-3254. 